\title{
Analisa Kebutuhan Sistem Informasi Manajemen Perusahaan Kayu Ukir (SIMPKU) (Studi Kasus CV. Embed)
}

\author{
Muhamad Azhari 1), Fahrul Agus ${ }^{2)}$ \\ ${ }^{1,2}$ Jurusan Ilmu Komputer FMIPA Universitas Mulawarman \\ Jalan Barong Tongkok No. 4 Kampus Gunung Kelua Samarinda, Kalimantan Timur \\ Email: m4zh4ri@gmail.com ${ }^{1)}$, fahrulagus@gmail.com ${ }^{2)}$
}

\begin{abstract}
ABSTRAK
Perkembangan bisnis yang terjadi pada perusahaan ukir-ukiran seharusnya diiringi dengan peningkatan kinerja setiap komponen dalam perusahan. Kompleksnya kegiatan di perusahaan kayu ukir menuntut pengelolaan informasi yang lebih baik. Saat ini perusahaan yang bergerak dalam bidang kayu ukir membutuhkan sebuah Sistem Informasi Manajemen Perusahaan Kayu Ukir (SIMPKU). Pengembangan SIMPKU diawali dengan proses analisis kebutuhan. Pada tahapan ini pemodelan use case menjadi alat dalam proses analisis tersebut. Identifikasi yang dilakukan menghasilkan aktifitas yang dilakukan oleh setiap pengguna SIMPKU. Sebanyak dua puluh empat event mampu diidentifikasi. Penelitian juga menghasilkan konstruksi table of event dan thing. Hal tersebut bermanfaat untuk proses pengembangan basis data SIMPKU.
\end{abstract}

Kata kunci : Sistem Informasi Manajemen, Kayu ukir, analis kebutuhan

\section{PENDAHULUAN}

Selain bernilai ekonomis bisnis kayu ukir juga berperan di dalam melestarikan kebudayaan bangsa yakni budaya seni ukir. Seiring perkembangan jaman, usaha kayu ukir-ukiran kini berkembang menjadi sebuah industri. Perusahaan ukir-ukiran dituntut untuk meningkatkan usaha dan pelayanan terhadap konsumen baik domistik dan mancanegara, baik pembelian secara eceran atau grosiran.

Tuntutan tersebut menjadi jembatan diterapkannya sistem informasi pada industri kayu ukir. Penerapaan sistem informasi berbasis komputer diharapkan akan meningkatan proses pengambilan keputusan yang cepat dan akurat, informasi semakin menyebar luas, pelayanan dan pekerjaan menjadi lebih efektif.

Pada pengembangan SIMPKU membutuhkan proses analisis kebutuhan. Hal ini dibutuhkan agar tidak terjadi kesalahan-kesalahan saat membangun sistem pada tahapan-tahapan selanjutnya. Kelak sistem yang dibangun akan sesuai dengan kebutuhan pengguna dan benar-benar dapat berfungsi dengan baik. Penelitian ini menggidentifikasi berbagai kebutuhan sistem sehingga hasilnya dapat menjadi acuan dalam proses pengembangan SIMPKU.

\section{RUANG LINGKUP}

Ruang lingkup penelitian mengacu pada kegiatan-kegiatan di perusahaan ukir-ukiran. Analisis kebutuhan yang dilakukan merupakan salah satu tahapan yang ada pada System Development Life Cycle (SDLC). Hasilnya diharapkan dapat menjadi acuan di dalam tahapan-tahapan proses pengembangan SIMPU.

\section{TUJUAN}

Penelitian bertujuan untuk menginventarisir dan mendokumentasikan kebutuhan-kebutuhan serta proses-proses yang terjadi dalam pengembangan Sistem Informasi Manajemen Perusahaan Kayu Ukir (SIMPKU).

\section{HASIL DAN PEMBAHASAN}

Pendekatan pengembangan sistem dimulai dengan proses pemodelan. Konsepnya mengacu pada aktifitas sistem atau use case. Use case adalah suatu aktivitas dari sistem yang ditampilkan dan biasanya merupakan akibat dari permintaan user. Teknik yang direkomendasikan untuk mengidentifikasi aktivitas/use case yakni Teknik Dekomposisi Event. Sebuah pendekatan dengan cara mendaftarkan semua pengguna (aktor), jenis-jenis kebutuhan dan tugasnya. Identifikasi pada tingkat use case secara detail dan tepat dilakukan dengan cara memfokuskannya pada dasar-dasar proses bisnis. Dasar proses bisnis sendiri merupakan suatu tugas yang ditampilkan pada satu tempat sebagai akibat dari satu kejadian bisnis. (Satzinger 2007).

Identifikasi pengguna pada SIMPKU yang menghasilkan model use case berikut.

\section{A. Daftar use-cases dengan identifikasi pengguna/pelaku SIMPKU}

Penelitian ini mengidentifikasi aktor dan use case yang ada pada perusahaaan kayu ukir seperti terlihat pada table 1 berikut. 
Tabel 1. Identifikasi use-cases dari SIMPU.

\begin{tabular}{|c|c|c|}
\hline No & Aktor & Use case \\
\hline 1. & Konsumen & $\begin{array}{ll}\text { a. } & \text { Melihat informasi tentang profil perusahaan ukir-ukiran. } \\
\text { b. Melihat katalog produk ukir-ukiran. } \\
\text { c. Membuat account user. } \\
\text { d. Mengisi form konsumen. } \\
\text { e. Membuat daftar pesanan produk ukir-ukiran. } \\
\text { f. Memperbaiki daftar pesanan produk ukir-ukiran. } \\
\text { g. Membatalkan daftar pesanan produk ukir-ukiran. } \\
\text { h. Melakukan pembayaran online produk yang dipesan (kartu kredit). } \\
\text { i. } & \text { Melakukan konfirmasi pembayaran produk pesanan via transfer BANK } \\
\text { j. } & \text { Mendapatkan id transaksi produk yang dipesan. } \\
\text { k. } & \text { Mendapatkan rekap data transakasi pembelian produk. } \\
\text { l. } & \text { Mendapatkan Informasi produk telah sampai dikirim. }\end{array}$ \\
\hline 2. & $\begin{array}{l}\text { Pegawai Divisi } \\
\text { Produksi }\end{array}$ & $\begin{array}{l}\text { a. Memasukkan data-data yang berkaitan dengan produksi (jumlah produksi } \\
\text { pada waktu tertentu, jenis produksi pada waktu tertentu, stok produksi). } \\
\text { b. Mendapatkan informasi daftar pesanan produk dari konsumen setiap waktu. } \\
\text { c. Memperbaiki data-data yang berkaitan dengan produksi (jumlah produksi } \\
\text { pada waktu tertentu, jenis produksi pada waktu tertentu). } \\
\text { d. Menghapus data-data yang berkaitan dengan produksi (jumlah produksi pada } \\
\text { waktu tertentu, jenis produksi pada waktu tertentu). } \\
\text { e. Membuat laporan kebutuhan produk jenis tertentu per satuan waktu. }\end{array}$ \\
\hline 3. & $\begin{array}{l}\text { Manajer Divisi } \\
\text { Produksi }\end{array}$ & $\begin{array}{l}\text { a. Mendapatkan Laporan daftar kebutuhan per jenis produk setiap satuan } \\
\text { waktu tertentu (hari, minggu, bulan, tahun). } \\
\text { b. Memasukkan data-data perencanaan produksi per satuan waktu tertentu. } \\
\text { c. Memperbaiki data-data perencanaan produksi persatuan waktu tertentu. } \\
\text { d. Menghapus data-data perencanaan produksi per satuan waktu tertentu. } \\
\text { e. Membuat Laporan berkala tentang Divisi Produksi (hari, minggu, bulan, } \\
\text { tahun). }\end{array}$ \\
\hline 4. & $\begin{array}{l}\text { Pegawai Divisi } \\
\text { Inventori }\end{array}$ & $\begin{array}{l}\text { a. Memasukkan data-data yang berkaitan dengan inventori (kapasitas material, } \\
\text { jenis material, kebutuhan material untuk tiap jenis produk, stok material). } \\
\text { b. Mendapatkan informasi daftar kebutuhan material berdasarkan perencanaan } \\
\text { produksi dari divisi produksi. } \\
\text { c. Memperbaiki data-data yang berkaitan dengan inventori (kapasitas material, } \\
\text { jenis material kebutuhan material untuk tiap jenis produk, stok material). } \\
\text { d. Menghapus data-dara yang berkaitan dengan inventori (kapasitas material, } \\
\text { jenis material kebutuhan material untuk tiap jenis produk,stok material). } \\
\text { e. Membuat laporan kebutuhan material tertentu per satuan waktu. }\end{array}$ \\
\hline 5. & $\begin{array}{l}\text { Manajer Divisi } \\
\text { Inventori }\end{array}$ & $\begin{array}{l}\text { a. Mendapatkan laporan daftar kebutuhan per jenis material setiap satuan waktu } \\
\text { tertentu (hari, minggu, bulan, tahun). } \\
\text { b. Memasukkan data-data perencanaan kebutuhan jenis material tertentu per } \\
\text { satuan waktu tertentu. } \\
\text { c. Memperbaiki data-data perencanaan kebutuhan jenis material tertentu per } \\
\text { satuan waktu tertentu. } \\
\text { d. Memghapus data-data perencanaan kebutuhan jenis material tertentu per } \\
\text { satuan waktu tertentu. } \\
\text { e. Membuat Laporan berkala tentang divisi Inventori. }\end{array}$ \\
\hline 6. & $\begin{array}{l}\text { Pegawai Divisi } \\
\text { Transportasi }\end{array}$ & $\begin{array}{l}\text { a. Memasukkan data-data yang berkaitan dengan transportasi (jenis transportasi, } \\
\text { biaya transportasi). } \\
\text { b. Mendapatkan informasi daftar lokasi konsumen. } \\
\text { c. Mendapatkan informasi daftar lokasi tujuan pengiriman produk. } \\
\text { d. Memperbaiki data-data yang berkaitan dengan transportasi (jenis transportasi, } \\
\text { biaya transportasi) } \\
\text { e. Menghapus data-data yang berkaitan dengan transportasi (jenis transportasi, } \\
\text { biaya transportasi). } \\
\text { f. Membuat laporan kebutuhan transportasi tertentu per satuan waktu. }\end{array}$ \\
\hline
\end{tabular}


Tabel 1. Identifikasi use-cases dari SIMPU (Lanjutan).

\begin{tabular}{|c|c|c|}
\hline No & Aktor & Use case \\
\hline 7 & $\begin{array}{l}\text { Manajer Divisi } \\
\text { Transportasi }\end{array}$ & $\begin{array}{l}\text { a. Mendapatkan laporan kebutuhan transportasi tertentu per satuan waktu. } \\
\text { b. Mendapatkan laporan pengiriman produk dari pegawai Divisi } \\
\text { cransportasi. } \\
\text { c. Memasukkan data-data perencanaan kebutuhan transportasi (jenis dan } \\
\text { lokasi tertentu) per satuan waktu tertentu. } \\
\text { d. Memperbaiki data-data perencanaan kebutuhan transportasi (jenis dan } \\
\text { lokasi tertentu) per satuan waktu tertentu. } \\
\text { e. Memghapus data-data perencanaan kebutuhan transportasi (jenis dan } \\
\text { lokasi tertentu) per satuan waktu tertentu. } \\
\text { f. Membuat Laporan berkala tentang divisi transportasi. }\end{array}$ \\
\hline 8. & $\begin{array}{l}\text { Pegawai Divisi } \\
\text { Keuangan }\end{array}$ & $\begin{array}{l}\text { a. Memasukkan data-data yang berkaitan dengan transaksi keuangan (biaya } \\
\text { operasional, gaji pegawai, dll). } \\
\text { b. Mendapatkan informasi biaya operasional dari tiap divisi. } \\
\text { c. Memperbaiki data-data yang berkaitan dengan transaksi keuangan (biaya } \\
\text { operasional, gaji pegawai, dll). } \\
\text { d. Menghapus data-data yang berkaitan dengan transaksi keuangan (biaya } \\
\text { operasional, gaji pegawai, dll). } \\
\text { e. Membuat laporan keuangan per satuan waktu. }\end{array}$ \\
\hline 9. & $\begin{array}{l}\text { Manajer Divisi } \\
\text { Keuangan }\end{array}$ & $\begin{array}{l}\text { a. Mendapatkan Laporan transaksi keuangan (hari, minggu, bulan, tahun). } \\
\text { b. Memasukkan data-data perencanaan biaya per satuan waktu tertentu. } \\
\text { c. Memperbaiki data-data perencanaan biaya. } \\
\text { d. Memghapus data-data perencanaan biaya per satuan waktu tertentu. } \\
\text { e. Membuat Laporan berkala tentang divisi Keuangan. }\end{array}$ \\
\hline 10. & $\begin{array}{l}\text { Pegawai Divisi } \\
\text { Pemasaran }\end{array}$ & $\begin{array}{l}\text { a. Memasukkan data-data yang berkaitan dengan produk tertentu (ukuran, } \\
\text { bahan) untuk katalog. } \\
\text { b. Mendapatkan informasi data tiap produk yang laku. } \\
\text { c. Memperbaiki data-data yang berkaitan dengan produk tertentu (ukuran, } \\
\text { bahan) untuk katalog. } \\
\text { d. Menghapus data-data yang berkaitan dengan produk tertentu (ukuran, } \\
\text { bahan) untuk katalog. } \\
\text { e. Membuat laporan penjualan tiap jenis produk pada satuan waktu } \\
\text { tertentu. }\end{array}$ \\
\hline 11 & $\begin{array}{l}\text { Manajer Divisi } \\
\text { Pemasaran }\end{array}$ & $\begin{array}{l}\text { a. Mendapatkan Laporan penjualan tiap jenis produk } \\
\text { (hari,minggu,bulan,tahun). } \\
\text { b. Memasukkan data-data perencanaan pemasaran per satuan waktu } \\
\text { tertentu. } \\
\text { c. Memperbaiki data-data perencanaan pemasaran per satuan waktu } \\
\text { tertentu. } \\
\text { d. Memghapus data-data perencanaan pemasaran per satuan waktu tertentu. } \\
\text { e. Membuat strategi dan perencanaan pemasaran. } \\
\text { f. Membuat Laporan berkala tentang divisi Pemasaran. }\end{array}$ \\
\hline 12 & Manajer Puncak & $\begin{array}{l}\text { a. Mendapatkan laporan perkembangan dari tiap-tiap divisi. } \\
\text { b. Membuat strategi dan perencanaan bisnis untuk satuan waktu tertentu. }\end{array}$ \\
\hline
\end{tabular}

Berdasarkan inventarisir yang dilakukan penelitian ini menghasilkan diagram use case. Pengembangan SIMPKU menggunakan diagram tersebut untuk membantu dalam merancang sistem.
Seperti terlihat pada gambar 1 berikut. Gambar menunjukkan kerja dan interaksi yang dilakukan oleh aktor terhadap sistem. 


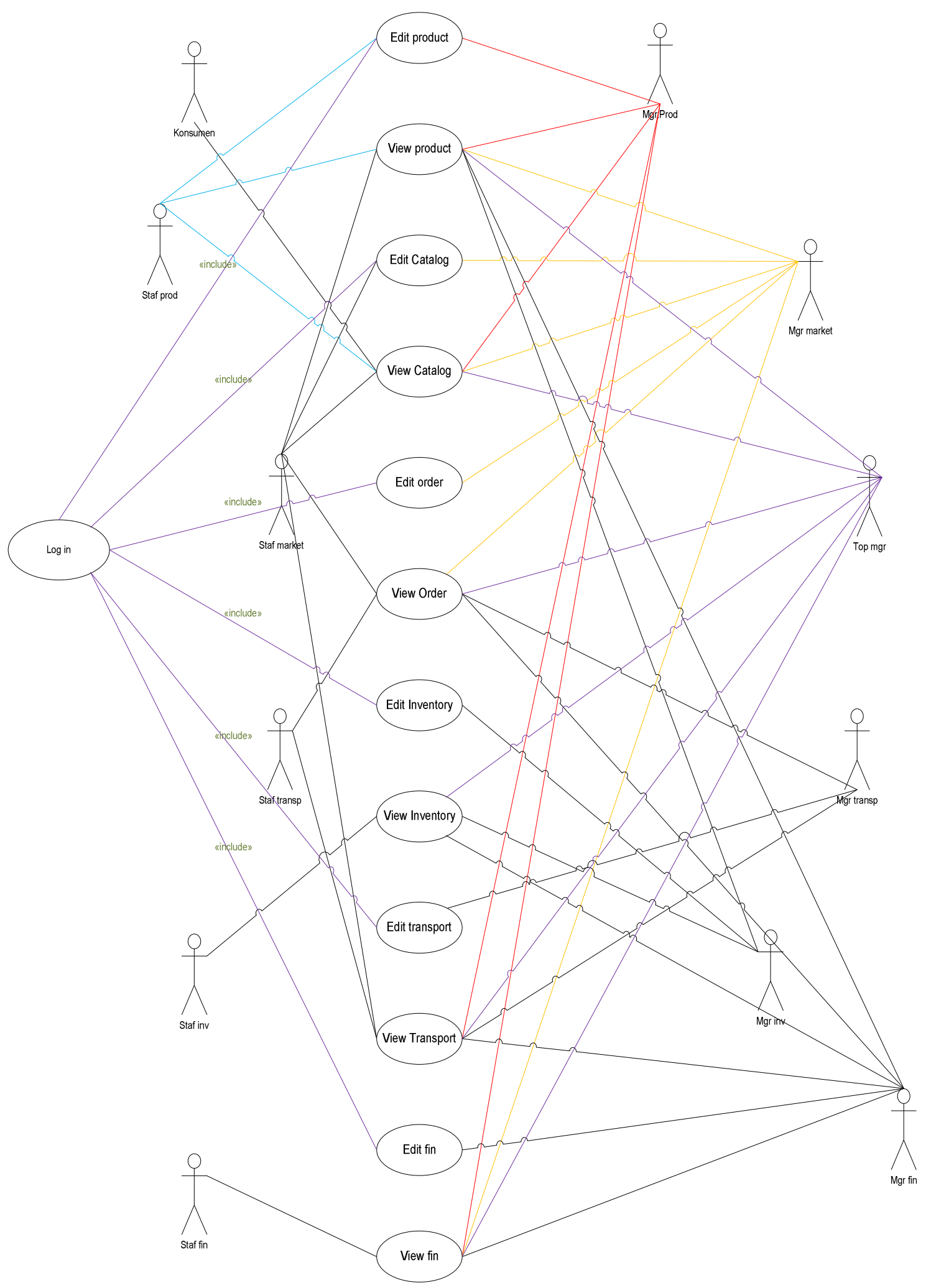

Gambar 1. Diagram use case SIMPKU

Selain diagram use case, pada penelitian ini juga dihasilkan daftar use case yang diidentifikasi berdasarkan event yang ada. Tabel
2 merupakan identifikasi yang dilakukan berdasarkan event yang ada pada perusahan kayu ukir. 
Tabel 2. Daftar use-cases berdasarkan identifikasi Events.

\begin{tabular}{|c|c|c|}
\hline No & Types of Events & Events \\
\hline 1. & External & 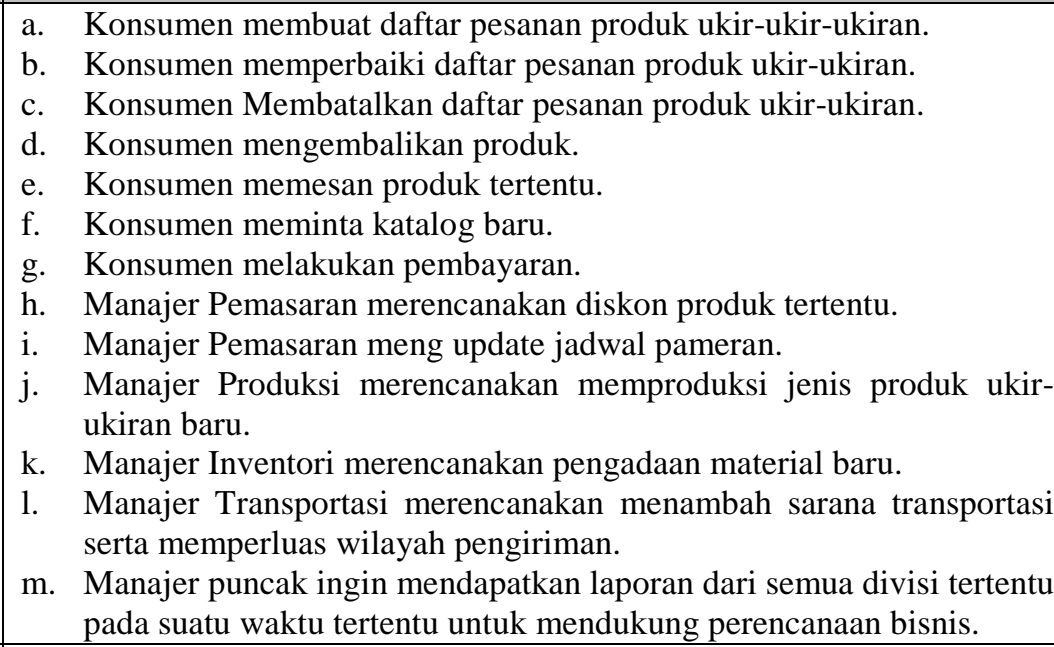 \\
\hline 2. & Temporary & $\begin{array}{l}\text { a. Pegawai Divisi Produksi mendapatkan laporan pesanan konsumen } \\
\text { pada setiap waktu tertentu. } \\
\text { b. Manajer Divisi Produksi mendapatkan Laporan daftar kebutuhan per } \\
\text { jenis produk setiap satuan waktu tertentu (hari, minggu, bulan, tahun). } \\
\text { c. Pegawai Divisi Inventori mendapatkan informasi daftar kebutuhan } \\
\text { material berdasarkan perencanaan produksi divisi produksi setiap } \\
\text { satuan waktu tertentu (hari, minggu, bulan, tahun). } \\
\text { d. Manajer Divisi Inventori mendapatkan laporan daftar kebutuhan per } \\
\text { jenis material setiap satuan waktu tertentu (hari, minggu, bulan, tahun). } \\
\text { e. Pegawai Divisi Transportasi mendapatkan informasi daftar lokasi } \\
\text { konsumen setiap satuan waktu tertentu (hari, minggu, bulan, tahun). } \\
\text { f. Manajer Divisi Transportasi mendapatkan laporan kebutuhan } \\
\text { transportasi tertentu per setiap satuan waktu tertentu (hari, minggu, } \\
\text { bulan, tahun). } \\
\text { g. Pegawai divisi keuangan mendapatkan informasi biaya operasional } \\
\text { dari tiap divisi setiap satuan waktu yang ditentukan. } \\
\text { h. Manajer Keuangan mendapatkan Laporan transaksi keuangan (hari, } \\
\text { minggu, bulan, tahun). } \\
\text { i. Pegawai Divisi Pemasaran mendapatkan informasi data tiap produk } \\
\text { jang laku. } \\
\text { Manajer Divisi Pemasaran mendapatkan Laporan penjualan tiap jenis } \\
\text { kroduk (hari, minggu, bulan, tahun). } \\
\text { kanajer puncak mendapatkan laporan kondisi tiap divisi setiap satuan } \\
\text { waktu tertentu. }\end{array}$ \\
\hline 3. & State & $\begin{array}{l}\text { a. Manajer Produksi mendapat laporan dari sistem jika pesanan jenis } \\
\text { barang tertentu melebihi kapasitas produksi. } \\
\text { b. Manajer Pemasaran mendapat laporan dari sistem jika penjualan telah } \\
\text { melebihi target sebelum batas waktu yang ditentukan. } \\
\text { c. Manajer Inventori mendapat laporan dari sistem jika persediaan } \\
\text { material telah mencapai batas tertentu sebelum waktu yang ditentukan. } \\
\text { d. Manajer Transportasi mendapat laporan dari sistem jika lokasi } \\
\text { konsumen berada di luar wilayah pengiriman. }\end{array}$ \\
\hline
\end{tabular}

\section{KESIMPULAN}

Analisis kebutuhan pada pengembangan SIMPKU menghasilkan simpulan:

1. Pengidentifikasian terhadap aktifitas pelaku/pengguna dapat dibuat model use case untuk pengembangan SIMPKU.
2. Pada pengembangan SIMPKU teridentifikasi 24 event.

3. Pangembangan SIMPKU dapat mengacu pada identifikasi use-cases berdasarkan type events sehingga akurasi SIMPKU akan dicapai. 


\section{DAFTAR PUSTAKA}

[1]. Maryani, Darudiato S. 2001. "Perancangan Rencana Strategis Sistem Informasi dan Teknologi Informasi (SI/TI) Studi Kasus STMIK XYZ. Bina Nusantara. Jakarta.

[2]. Satzinger W et al. 2007. Systems Analysis and Design in a Changing World. $4^{\text {th }}$ Edition. Massachusetts : Thomson Course Technology.
[3]. Sawitri D. 2009. "Perancangan Sistem Informasi Manajemen Persediaan Barang Elektrolux Authorized Service CV. Momentum Teknik”. Gunadarma. Depok.

[4]. Llah F, 2011. "Potensi Ukiran Kayu". Universiti Malaysia Kelantan. 